\title{
Doğal ve Mekanik Yöntemlerle Kurutularak Farklı Şekillerde Paketlenen Hamsi Balıklarında (Engraulis encrasicolus L., 1758) Kalite Değişimlerinin Belirlenmesi
}

\author{
Fatih YAVUZ1 ${ }^{1}$, Mehmet Emin ERDEM ${ }^{2}$, Bayram KÖSTEKLI ${ }^{3}$, İrfan KESKIN ${ }^{4}$, Asiye EYUBOĞLU5 \\ Sinop Universitesi, Su Ürünleri Fakültesi, Su Ürünleri Avlama ve İşleme Teknolojisi, Akliman Mevkii Dibekli Köyü, 57000, Sinop \\ ${ }^{1}$ https://orcid.org/0000-0003-0721-7408, ${ }^{2}$ https://orcid.org/0000-0002-3245-8177, ${ }^{3}$ https://orcid.org/0000-0003-4279-6257 \\ ${ }^{4} \mathrm{https} / / /$ orcid.org/0000-0003-4503-7299, ${ }^{5} \mathrm{https}: / /$ orcid.org/0000-0003-3571-3222 \\ $\square$ : bkostekli@sinop.edu.tr
}

\section{ÖZET}

Çalışmada, hamsi balıkları doğal ve mekanik kurutma yöntemleriyle kurutulmuş, streç ve vakum paketleme yöntemleri ile de paketlenmiştir. Buzdolabı koşullarında $\left(4 \pm 1^{\circ} \mathrm{C}\right)$ muhafaza altına alınan balıkların kalite değişimlerini ve raf ömrünü belirlemek amacıyla; kimyasal, mikrobiyolojik ve duyusal analizler yapılmıştır. Balık etinin kurumasina bağlı olarak tüm grupların TBA ve TVB-N analiz sonuçlarında ani bir artış gözlemlenmiştir ve bu artışın raf ömrü süresince devam ettiği belirlenmiştir. Su aktivitesinin çok düşük olmasından dolayı çalışma boyunca mikroorganizma sayısı tespit edilebilir sınır değerin $(10 \mathrm{kob} / \mathrm{g})$ altında kalmıştır. Mikrobiyolojik verilere göre tüm gruplarda çalışma boyunca koliform grubu bakteri tespit edilmemiştir. Yapılan duyusal analiz sonucuna göre, mekanik yöntemle kurutulan hamsi balıklarının raf ömrü 2 ay, doğal yöntemle kurutulan hamsilerin ise raf ömrü 2,5 ay olarak belirlenmiştir. $\mathrm{Bu}$ çalışmada, vakum paketlemenin ürün üzerinde zamanla dehidrasyona ve dokularında bir miktar bozulmaya neden olduğu tespit edilmiştir.

\section{Araştırma Makalesi}

\author{
Makale Tarihçesi \\ Geliş Tarihi : 27.05 .2020 \\ Kabul Tarihi : 09.07.2020
}

Anahtar Kelimeler

Hamsi

Doğal kurutma

Mekanik kurutma

Vakum paket

Raf ömrü

Determination of Quality Changes on Anchovy (Engraulis encrasicolus L., 1758) Dried with Natural and Mechanical Methods and Packaged in Various Forms

\section{ABSTRACT}

In study, anchovies were dried with natural and mechanical methods and were packaged by stretch and vacuum methods. In order to determine the quality changes and shelf-life of the fish that were stored in refrigerator $\left(4 \pm 1^{\circ} \mathrm{C}\right)$; chemical, microbiologic and sensorial analysis were performed. Due to the drying of fish meat, a sudden increase was observed in TBA and TVB-N analysis and it was determined that this increase continues throughout the shelf life of all groups. Due to the very low water activity, the number of microorganisms remained below the detectable limit (10 CFU g) throughout the study. When the microbiologic data was examined, coliform bacteria were not found throughout the research. According to the sensory analysis, the shelf life of anchovy fish was determined as 2.5 months by drying naturally and the shelf life of the anchovy fish was extended 2 months through mechanical drying. In the present study, it was detected that vacuum packaging cause hydration over time and some spoiling in their texture.

\section{Research Article}

$\begin{array}{ll}\text { Article History } \\ \text { Received } & : 27.05 .2020 \\ \text { Accepted } & : 09.07 .2020\end{array}$

\author{
Keywords \\ Anchovy \\ Natural drying \\ Mechanical drying \\ Vacuum packaging \\ Shelf-life
}

\footnotetext{
Atıf İçin: $\quad$ Yavuz F, Erdem ME, Köstekli B, Keskin İ, Eyüboğlu A 2021. Doğal ve Mekanik Yöntemlerle Kurutularak Farklı Şekillerde Paketlenen Hamsi Balıklarında (Engraulis encrasicolus L., 1758) Kalite Değişimlerinin Belirlenmesi. KSÜ Tarım ve Doğa Derg 24 (1): 156-164. https://doi.org/10.18016/ksutarimdoga.vi.743235.

To Cite: $\quad$ Yavuz F, Erdem ME, Köstekli B, Keskin İ, Eyüboğlu A 2021. Determination of Quality Changes on Anchovy (Engraulis encrasicolus L., 1758) Dried with Natural and Mechanical Methods and Packaged in Various Forms. KSU J. Agric Nat 24 (1): 156-164. https://doi.org/10.18016/ksutarimdoga.vi.743235.
}

\section{GIRIŞ}

Gelişen dünyada artan nüfus ve beslenme, insanlığın karşılaştığ edilmektedir. Küresel olarak üretilen gıdaların üçte birinden fazlasının atık veya bozulmaya uğraması nedeniyle gıdaların korunması çok önemlidir 
(Köstekli, 2019).

Ayrıca, beslenme de bu meselelerin başında gelmektedir. Doğru beslenme için protein, yağ, karbonhidrat ve vitaminden oluşan dört temel besin grubundan yeterli şekilde yararlanmak gerekmektedir. Su ürünleri protein açısından oldukça zengin olup esansiyel amino asitleri, doymamış yağları yüksek miktarda içermesi ile bunun yanında A vitamini, $\mathrm{D}$ vitamini $\mathrm{K}$ vitamini ve $\mathrm{B}$ grubu vitaminleri (örn., B1, B2, B6, B12), iyot, selenyum, fosfor, magnezyum ve çinko minerallerini barındırması bakımından da iyi bir kaynaktır (Anonim, 2020).

Su ürünleri genellikle herhangi bir işleme yöntemine tabii tutulmadan taze olarak tüketilmekle birlikte, dondurulmuş, marine edilmiş, konserve edilmiş, tütsülenmiş, surimi yapılmış, tuzlanmış ve kurutulmuş olarak da tüketilmektedir.

Türkiye'de çeşitli nedenlerden ötürü su ürünleri daha çok taze olarak ve ürünlerin avlandığı bölgelerde ve avlandığ 1 mevsiminde tüketilmektedir. Bunun nedenleri; tuzlama, kurutma, dumanlama ve konserve gibi diğer değerlendirme şekillerinin Türkiye'de yaygınlaşmaması olarak düşünülmektedir (Turan, 1996). Ancak bölgesel olarak bakıldığında Doğu Karadeniz bölgesinde tuzlama, Doğu Anadolu bölgesinde inci kefali kurutma yaygin olarak kullanılmaktadır.

Bu işleme yöntemlerinden biri olan kurutma yöntemi, mikroorganizma gelişiminin engellenmesi, kimyasal reaksiyonların yavaşlatılması veya durdurulması amaciyla suyun gidalardan buharlaştırılarak uzaklaştırılması prensibine dayanan bir işleme yöntemidir. (Geankoplis, 1993; Cohen ve Yang, 1995).

Geçmişte ve günümüzde yaygın olarak kullanılan kurutma tekniklerinden biri ürünün açık havada doğal kurutulmasıdır. Ürün içinde bulunan nemin uzaklaştırılması için gerekli olan gizli ısı ihtiyacı hava tarafindan sağlanarak, buharlaşan su kurutulacak üründen doğal ortamlarda uzaklaştırılmaktadır. Hava ile ürün arasında ısı ve nem transferi aynı anda gerçekleştirilir ve bu şekilde ürünün su aktivitesi de düşürülür (Bingöl, 2010). Bu yöntemde kontrol zorluğu, hava koşulları, yer, iş̧̧ilik ve hijyen gibi faktörler dezavantajdır (Erdem ve ark., 2016).

Makinelerde mekanik olarak kurutma metodu ise, kurutma dolabı veya kurutma tünelleri gibi kapalı ortamlarda, şartları istenilen kriterlerde ayarlanabilen, doğal, tuzlanmış ve haşlanmış ürünlerin kısa zamanda daha fazla miktarda kurutulabildiği, işlemin kontrolü sağlandığı için kurutma oranı ve besindeki su yüzdesi istenen değerde sabit tutulabilen kurutma yöntemidir (MEGEP, 2008).

Kurutulmuş ürünlerin kalitesine etki eden önemli etmenlerden birisi de ambalaj uygulamasıdır. Ambalaj gıdayı çevresel etmenlerden koruyan, nakliyesini, satışını ve tüketimini kolaylaştıran kağıt, metal, plastik ve cam gibi malzemelerden yapılabilmektedir (Keleş, 1998)

Kuru ürünlerin depolama raf ömrü bu uygulanan ambalajın niteliğine direk olarak bağlıdır. Kurutulmuş gıdalarda ambalaj sisteminde gidanın su buharı ve özellikle gıda içerisindeki yağ bileşimlerinden dolayı gaz geçirimsizliği istenmektedir. Gıda içerisindeki yağ asitleri, oksijenle temas ettiğinde oksidasyona neden olur ve bunun sonucunda, renk ve tat değişikliği meydana gelir. Hatta bu reaksiyonlar paketleme işlemi bittikten sonra da bir süre devam eder. Dolayısıyla bu tür aktivitelerin azaltılması gerekmektedir (Baysal ve ark., 2013).

Bu çalışmada doğal ve yapay kurutma yöntemlerinin uygulandığ $\breve{1}_{1}$ hamsi filetolarının kalitesinin tespit edilmesi ve ayrıca farklı paketleme yöntemleri uygulayarak da raf ömrünün değişiminin araştırılması amaçlanmıştır.

\section{MATERYAL ve METOD}

\section{Materyal}

Araştırma materyali olarak Sinop balıkçı tezgâhından temin edilen, ortalama boyu $11.12 \pm 0.18 \mathrm{~cm}$ ve ortalama ağırlığ $8,81 \pm 0,35$ gr olan toplam $10 \mathrm{~kg}$ taze hamsi balığı buzlanarak, strafor kutulara konulmuş ve ivedi olarak laboratuvara getirilmiştir. Hamsi balıkları; baş, iç organlar ve omurgalarından arındırılarak fileto haline getirilmiş ve iyice yıkanan filetolar daha sonra kan ve mukuslarından arındırmak amaciyla \%10'luk tuzlu su salamurasinda 1 saat bekletilmiştir ve sonrasında ise sızdırılmıştır.

\section{Tuzlama-kurutma ve gruplandirma}

Tuzlama işlemi delikli bir kap içerisinde bir kat tuz ve bir kat balık olacak şekilde balık ağırlığının \%10'u ağırlığın da kaya tuzu (3-5mm) kullanılarak yapılmıştır. Balıklar dizilip tuzlandıktan sonra üzerlerine temiz bir baskı taşı konulmuş ve buzdolabında 24 saat bekletilmiştir. Kuru tuzlanan hamsi balıkları 24 saat sonra buzdolabından çıkarılarak fazla tuzundan arındırmak için yıkanmıştır ve sızdırılmıştır. Bu aşamadan sonra hamsi balıkları iki farklı şekilde (Doğal ve mekanik) kurutulmak üzere ikiye ayrılmıştır. Doğal kurutulacak olan birinci grup hamsi balıkları laboratuvar ortamında kurutma askıları üzerine dizilmiştir. Daha sonra hamsi balıklarının üzeri böcek ve haşerelerden koruma amaciyla tül ile örtülmüş ortalama $\% 60$ nem ve $22^{\circ} \mathrm{C}$ 'de laboratuvar ortamında 96 saat boyunca kurutulmaya bırakılmıştır. İkinci grup hamsi balıkları; mekanik yöntemle kurutulmak için iklimlendirme test kabininin içerisinde tepsilere dizilerek sabit $45^{\circ} \mathrm{C}^{\prime} \mathrm{de} \% 30$ nem oranında 32 saat boyunca kurutulmuştur. Gruplar; doğal yöntemle kurutulmuş ve streç film ile paketlenmiş hamsi 
balıkları (Grup A), doğal yöntemle kurutulmuş ve vakum uygulanarak paketlenmiş hamsi balıkları (Grup B), mekanik yöntemle kurutulmuş ve streç film ile paketlenmiş hamsi balıkları (Grup C) ve mekanik yöntemle kurutulmuş vakum uygulanarak paketlenmiş hamsi balıkları (Grup D) olarak oluşturulmuştur. Tüm gruplar buzdolabı koşullarında $\left(4 \pm 1^{\circ} \mathrm{C}\right)$ muhafaza edilmiştir.

\section{Fiziko-Kimyasal Analizler}

Kurutulmuş hamsi örneklerinde $\mathrm{pH}$ ölçümü, Curran ve ark.'larının (1980) bildirdiği yönteme göre kimyasal analizlerden; TVB-N tayini Antonacopoulas tarafindan modifiye edilmiş Lucke-Geidel metoduna göre (İnal, 1992; Varlık ve ark., 1993), Tiyobarbitürik asit tayini (TBA) ise Tarladgis yöntemine göre (Smith ve ark., 1992; Varlık ve ark., 1993; Yakupitiyage, 1994) yapılmıştır. Su aktivitesi analizi ise numune kaplarına 3-5 g homojenize edilmiş örnek konularak su aktivitesi (Novasina marka, EW-37910-14 model) cihazı ile ölçülmüştür.

\section{Mikrobiyolojik Analizler}

Toplam mezofilik aerobik bakteri ve toplam psikrofilik aerobik bakteri sayımı Gürgün ve Halkman'nın (1990) bildirdiği yönteme göre, maya-küf sayımı Roger ve ark., (1987) Göktan (1990), ve Varlık ve ark.'larının (1993) bildirdiği yönteme göre, Toplam Koliform bakteri sayımı ise Roger ve ark.'larının (1987) bildirdiği yönteme göre yapılmıştır, Toplam mezofilik aerobik bakteri ve toplam psikrofilik aerobik bakteri sayımı için Plate Count Agar (PCA), (LabM 149) besi yeri, Maya-küf sayımı için PDA (Potato Dextroz Agar) (Lab M 98) besi yeri, Toplam Koliform bakteri sayımı için ise VRBA (Violet Red Bile Agar) (Lab M 31) besiyeri kullanılmıştır.

\section{Duyusal Analizler}

Duyusal analiz için kurutulmuş hamsi örnekleri tabaklara konularak etiketlendirilip panelistlere sunulmuştur. Beş kişilik deneyimli panelist grup tarafindan kurutulmuş hamsilerin görünüş, koku, tat ve tekstür kriterleri değerlendirilmiştir. Kurutulmuş hamsilerin duyusal değerlendirilmesi her örnekte puan kriterleri bakımından 1 ile 10 arasında bir puanlama yapılarak sağlanmıştır (1-2: tüketilemez, 34: tüketilebilir, 5-6: orta kalite, 7-8: iyi, 9-10: mükemmel). Depolama süresince boyunca analizlerin yapıldığı günlerde örnekler duyusal olarak da değerlendirilmiştir. 3 puanın altında puanlanan ürünler "Tüketilemez" olarak değerlendirilmiştir (Altuğ, 1993).

\section{İstatistik Analiz}

Araştırmada elde edilen sonuçların ortalama ve standart hataları Microsoft Office Excel 2010 istatistik değerlendirme Minitab 17 paket programı yardımıyla yapılmıştır. Çalışmada tek yönlü varyans analizi yapılmış ve gruplar arası farklılık Tukey testi ile belirlenmiştir. (Düzgüneş ve ark., 1993; Özdamar, 1999).

\section{BULGULAR ve TARTIŞMA}

Su ürünlerinin değerlendirilmesinde önemli bir kriter olan TVB-N analiz değeri bu çalışmada başlangiçta taze hamsi balığında $16.62 \pm 0.25 \mathrm{mg} 100 \mathrm{~g}$ iken depolamanın son gününde $\mathrm{A}, \mathrm{B}, \mathrm{C}$ ve $\mathrm{D}$ gruplarında sirasiyla $45.57 \pm 0.25 \mathrm{mg} 100 \mathrm{~g}, 39.26 \pm 0.17 \mathrm{mg} 100 \mathrm{~g}$, $48.28 \pm 0.43 \mathrm{mg} 100 \mathrm{~g}, 42.88 \pm 0.31 \mathrm{mg} 100 \mathrm{~g}$ olarak tespit edilmiştir. Doğal ve mekanik kurutulmuş gruplarda TVB-N değerlerinin artışının 1. günden itibaren başladığı ve depolama süresinin 30. gününden itibaren gruplar arasındaki fark istatistiki açıdan önemli bulunmuştur $(\mathrm{P}<0.05)$ (Çizelge 1$)$.

İnal'a göre tazeliğini kaybetmemiş balık etinin TVB-N değeri 25-30 mg 100g arasında olup tüketilebilirlik sınır değeri 30-35 mg 100g arasındadır. Fakat balık etindeki nem kaybına bağ olarak oransal artışların olması muhtemeldir. Kurutulmuş su ürünleri nem miktarı düşük olduğu için bu değerin yüksek olması tolere edilebilir bir durum olduğu ifade edilmiştir (İnal, 1992).

Srinivasa ve ark. (1998), yaptıkları çalışmada kurutulmuş hamsilerin farklı ambalajlarda raf ömrünün streç ambalaj paketlemede 12 hafta, yüksek yoğunluklu polietilen paketlerde ise 32 hafta olduğunu tespit etmişler ve TVB-N değerinin depolamanın 4. ayında artarak $36.4 \mathrm{mg} 100 \mathrm{~g}$ ulaştı̆̆

Shiriskar ve ark. (2013) Hint hamsisi Stolephorus indicus (Van Hasselt, 1823) ve Stolephorus commersonii (Lacepède, 1803) üzerinde yaptıkları çalışmada hamsilerde tropikal ortam sıcaklığında kurutma işlemi uygulanmış ve 5. hafta sonunda TVB$\mathrm{N}$ değerini $27.1 \pm 1.18 \mathrm{mg} \quad 100 \mathrm{~g}$ olarak tespit etmişlerdir.

TVB-N değerlerindeki farklılıkların ele alınmasında kurutulan balığın türü, mikrobiyal aktivitesi, ortamın nemi, sicaklığ 1 ve tuzun konsantrasyonu gibi faktörlerin göz önüne alınması elzemdir. Yapılan çalışmada, TVB-N analizi sonuçlarının yüksek çıkması kurutmaya bağlı olarak alınan et örneğindeki suyun çok düşük olmasından kaynaklanmaktadır. TVB-N oransal açıdan yüksek çıkmıştır. Bu durum su aktivitesi bulguları ile de desteklenmiştir. Çalışmada kurutma sonrası hamsi ile literatürde bildirilen TVB$\mathrm{N}$ değerlerindeki farklılıklar bu sebeplerle ilgili olduğu düşünülmektedir.

Yapılan TBA analizi sonucuna göre depolama boyunca doğal kurutma ve mekanik kurutma gruplarının günlük değişimlerinde 15. güne kadar istatistiki farklılık gözlenmez iken 30.gün ve sonraki değişimler istatistiki olarak anlamlı bulunmuştur $(\mathrm{P}<0.05)$. 
Yapılan TBA analizi sonucuna göre taze hamsi balıklarında 0.31 $\pm 0.01 \mathrm{mg}$ MDA kg olan değer tuzlama

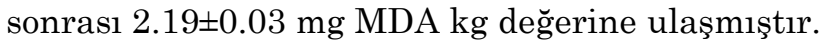

Çizelge 1. Kurutulmuş hamsilerin depolama süresi boyunca TVB-N miktarlarındaki değişim (mg 100g). Table 1. Changes in TVB-N amounts of dried anchovies during the storage period (mg $100 \mathrm{~g}$ ).

\begin{tabular}{|c|c|c|c|c|}
\hline \multirow{2}{*}{ Günler/Days } & \multicolumn{4}{|c|}{ TVB-N (mg 100g) } \\
\hline & A grubu/ Group $A$ & B grubu/ Group $B$ & C grubu/ Group $C$ & D grubu/ Group $D$ \\
\hline Taze balık/ Fresh fish & $16.62 \pm 0.25^{\mathrm{h}}$ & $16.62 \pm 0.25^{\mathrm{h}}$ & $16.62 \pm 0.25^{\mathrm{f}}$ & $16.62 \pm 0.25^{\mathrm{e}}$ \\
\hline Tuzlama Sonrası/After dry salting & $12.22 \pm 0.24^{\mathrm{g}}$ & $12.22 \pm 0.24^{\mathrm{g}}$ & $12.22 \pm 0.24^{\mathrm{e}}$ & $12.22 \pm 0.24^{\mathrm{f}}$ \\
\hline $1 . *$ & $32.41 \pm 0.47 \mathrm{fB}$ & $31.69 \pm 0.31^{\mathrm{fB}}$ & $39.82 \pm 0.26^{\mathrm{dA}}$ & $40.30 \pm 0.21^{\mathrm{cdA}}$ \\
\hline 15.* & $36.82 \pm 0.16^{\mathrm{eC}}$ & $35.93 \pm 0.28^{\mathrm{eC}}$ & $39.42 \pm 0.34^{\mathrm{dB}}$ & $40.63 \pm 0.30^{\mathrm{cdA}}$ \\
\hline 30.* & $39.23 \pm 0.21^{\mathrm{dC}}$ & $37.54 \pm 0.26^{\mathrm{dD}}$ & $44.61 \pm 0.28^{\mathrm{cA}}$ & $40.97 \pm 0.38^{\mathrm{cdB}}$ \\
\hline 45.* & $41.67 \pm 0.17 \mathrm{cB}$ & $38.77 \pm 0.40^{\mathrm{cdC}}$ & $43.98 \pm 0.14^{\mathrm{cA}}$ & $40.80 \pm 0.28^{\mathrm{cdB}}$ \\
\hline 60.* & $42.55 \pm 0.21^{\mathrm{bcB}}$ & $40.26 \pm 0.28^{\mathrm{abC}}$ & $46.44 \pm 0.14^{\mathrm{bA}}$ & $39.90 \pm 0.46^{\mathrm{dC}}$ \\
\hline 70.* & $43.26 \pm 0.15^{\mathrm{bB}}$ & $38.82 \pm 0.20^{\mathrm{cD}}$ & $46.43 \pm 0.16^{\mathrm{bA}}$ & $41.40 \pm 0.19^{\mathrm{bcC}}$ \\
\hline 75.* & $42.98 \pm 0.40^{\mathrm{bB}}$ & $40.66 \pm 0.22^{\mathrm{aC}}$ & $47.73 \pm 0.32^{\mathrm{abA}}$ & $42.97 \pm 0.38^{\mathrm{aB}}$ \\
\hline 80.* & $45.57 \pm 0.25^{\mathrm{aB}}$ & $39.26 \pm 0.17 \mathrm{bcD}$ & $48.28 \pm 0.43^{\mathrm{aA}}$ & $42.88 \pm 0.31^{\mathrm{abC}}$ \\
\hline
\end{tabular}

$\mathrm{A}, \mathrm{B} \rightarrow$ : Aynı satırda gruplar arasında fark önemli $(\mathrm{P}<0.05)$

$a b \downarrow$ : Aynı sütunda zamana göre günler arasındaki fark önemli $(\mathrm{P}<0.05)$

*: Kurutma sonrası analizlerin gerçekleştirildiği günler.

Depolamanın son günü (80.gün) TBA değerlerinde artış gözlemlenmiş ve 80.günde A, B, C ve D gruplarındaki değerler ise sirasıyla $17.78 \pm 0.35$, $14.18 \pm 0.20,20.57 \pm 0.25$ ve $16.53 \pm 0.25 \mathrm{mg}$ MDA kg olarak tespit edilmiştir (Çizelge 2).

TBA sayısının tüketilebilirlik sınır değerinin ise 7-8 mg MDA kg arasında olduğu bildirilmiştir (Varlık ve ark., 1993).

Chavan ve ark. (2008), yaptıkları mekanik kurutulmuş uskumru balıklarının 4 aylık depolama süresi sonundaki TBA değerini $2.7 \pm 0.06 \mathrm{mg}$ MDA kg olarak tespit etmişlerdir.

Kaba ve ark. (2012), hamsi balıklarından kurutulmuş pate yaptıkları çalışmada deneme başında taze örneklerde TBA değerini $1.25 \mathrm{mg}$ MDA kg hamsi patelerinde ise $1.37 \mathrm{mg}$ MDA $\mathrm{kg}$ olarak tespit etmişlerdir. Deneme sonunda ise 8 . günde patelerin TBA değerini $6.78 \mathrm{mg}$ MDA kg olarak tespit etmişlerdir.

Araştırmada deneme başında tespit edilen değerler literatür ile uyumlu olup depolamanın son günündeki değerlerin yüksekliği işleme süreçlerinin ve uygulandığı balık türünün farklılığından kaynaklı yağ miktarı fazlalığı ve serbest yağ asidi içeriğinden ileri geldiği düşünülebilir. Ayrıca işleme sürecinde TBA değerindeki artış, balıketindeki kısmi dehidrasyona ve doğal kurutma ile doymamış yă̆ asitlerinin oksidasyonunun artmasi sonucuyla değerlendirilebilir.

Çizelge 2. Kurutulmuş hamsilerin depolama süresi boyunca TBA miktarlarındaki değişim (mg MDA kg).

Table 2. Changes in TBA amounts of dried anchovies during the storage period (mg MDA kg).

\begin{tabular}{|c|c|c|c|c|}
\hline \multirow{2}{*}{ Günler/Days } & \multicolumn{4}{|c|}{ TBA (mg MDA kg) } \\
\hline & A grubu/ Group $A$ & B grubu/ Group $B$ & $\mathrm{C}$ grubu/ Group $C$ & D grubu/Group $D$ \\
\hline Taze balık/ Fresh fish & $0.31 \pm 0.01^{\mathrm{g}}$ & $0.31 \pm 0.01^{\mathrm{e}}$ & $0.31 \pm 0.01^{\mathrm{e}}$ & $0.31 \pm 0.01^{\mathrm{f}}$ \\
\hline Tuzlama Sonrası/After dry salting & $2.19 \pm 0.03^{\mathrm{f}}$ & $2.19 \pm 0.03^{\mathrm{d}}$ & $2.19 \pm 0.03^{\mathrm{d}}$ & $2.19 \pm 0.03^{\mathrm{e}}$ \\
\hline $1 .^{*}$ & $5.70 \pm 0.16^{\mathrm{eA}}$ & $5.55 \pm 0.16^{\mathrm{cA}}$ & $6.16 \pm 0.22^{\mathrm{cA}}$ & $6.21 \pm 0.16^{\mathrm{dA}}$ \\
\hline 15.* & $14.83 \pm 0.39 \mathrm{~dB}$ & $12.07 \pm 0.08^{\mathrm{bD}}$ & $16.52 \pm 0.20^{\mathrm{bA}}$ & $13.34 \pm 0.12^{\mathrm{cC}}$ \\
\hline $30 .^{*}$ & $16.50 \pm 0.31^{\mathrm{bB}}$ & $13.53 \pm 0.19^{\mathrm{aC}}$ & $19.43 \pm 0.16^{\mathrm{aA}}$ & $15.60 \pm 0.21^{\mathrm{bB}}$ \\
\hline 45.* & $18.42 \pm 0.22^{\mathrm{abB}}$ & $13.76 \pm 0.36^{\mathrm{aD}}$ & $20.36 \pm 0.27 \mathrm{aA}$ & $16.16 \pm 0.10^{\mathrm{abC}}$ \\
\hline 60.* & $19.07 \pm 0.22^{\mathrm{aA}}$ & $13.68 \pm 0.35^{\mathrm{aC}}$ & $20.13 \pm 0.28^{\mathrm{aA}}$ & $16.22 \pm 0.17 \mathrm{abB}$ \\
\hline 70.* & $18.15 \pm 0.18^{\mathrm{abB}}$ & $14.46 \pm 0.46^{\mathrm{aD}}$ & $20.17 \pm 0.49^{\mathrm{aA}}$ & $16.09 \pm 0.17 \mathrm{abC}$ \\
\hline 75.* & $18.25 \pm 0.19 \mathrm{abB}$ & $14.53 \pm 0.23^{\mathrm{aD}}$ & $19.96 \pm 0.13^{\mathrm{aA}}$ & $16.22 \pm 0.19^{\mathrm{abC}}$ \\
\hline 80.* & $17.78 \pm 0.35^{\mathrm{bB}}$ & $14.18 \pm 0.20^{\mathrm{aD}}$ & $20.57 \pm 0.25^{\mathrm{aA}}$ & $16.53 \pm 0.25^{\mathrm{aC}}$ \\
\hline
\end{tabular}

A, B: Aynı satırda gruplar arasında fark önemli $(\mathrm{P}<0.05)$

a. b: Aynı sütunda zamana göre günler arasındaki fark önemli $(\mathrm{P}<0.05)$

*: Kurutma sonrası analizlerin gerçekleştirildiği günler.

Çalışmada pH değeri zaman içerisinde dalgalanmalar göstermiştir. Doğal kurutma işlemine tabi tutulan grupta depolamanın 1. gün ve 70. gün arasında $\mathrm{pH}$ değerinde artış görülüp istatistiki açıdan önemli 
bulunurken $(\mathrm{P}<0.05)$; $\mathrm{C}$ grubunun 30 . ve 80 . günleri ve $\mathrm{D}$ grubun 15.gün ve 60.günleri arasındaki farkın istatistiki açıdan önemli olmadığı belirlenmiştir $(\mathrm{P}>0.05)$. Depolama süresince $\mathrm{pH}$ değeri gruplarda artış göstermiştir ve 60.günden itibaren gruplar arası değer artışı istatistiki açıdan farklı bulunmuştur $(\mathrm{P}<0.05)$. Ham materyalde elde edilen $\mathrm{pH}$ değeri $6.52 \pm 0.02$ tuzlama sonrası ise $6.30 \pm 0.01$ değerine düşmüştür. Depolamanın son günü bu değerler A, B, C ve D gruplarinda sirasiyla $6.89 \pm 0.01,6.86 \pm 0.02$, $6.95 \pm 0.01$ ve $7.10 \pm 0.02$ olarak bulunmuştur (Çizelge 3.). Taze balıklarda $\mathrm{pH}$ değeri nötre yakındır. Ancak balık dokusunda bozulma ve kokuşma başlarsa $\mathrm{pH}$ 7.08.0 düzeyine yükselebilmektedir. $\mathrm{pH}$ değeri için tüketilebilirlik sınır değeri 6.8-7.0 olarak bildirilmektedir (Varlık ve ark., 1993).

Yapar (1999), yaptığı çalışmada taze hamsi balığında pH değerini 6.22 olarak tespit etmiştir. Depolamanın 10. haftasında $\mathrm{pH}$ değerlerini \% 7.5'luk tuz konsantrasyonunda 6.27. \%10'luk tuz konsantrasyonunda 6.25. \%15'lik tuz konsantrasyonunda 6.30 olarak tespit etmiştir. Azam ve ark. (2003) tarafından yerel balık pazarından kurutulmuş halde alınan balıklardan elde edilen $\mathrm{pH}$ değerleri surasiyla; Mugil cephalus $7.93 \pm 0.09$, Scoliodon sorrakowah $8.27 \pm 0.04$, Setipinna phasa $8.03 \pm 0.05$, Harpodon nehereus $8.07 \pm 0.05$, Arius caelatus $8.27 \pm 0.06$, Hilsa ilisha $8.03 \pm 0.07$, Polynemus paradiseus $8.23 \pm 0.15$, Trichuirus haumella $7.67 \pm 0.05$, Pampus chinenchis $8.13 \pm 0.12$, Himantura walga

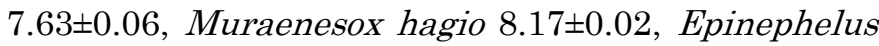
lanceolatus $8.03 \pm 0.03, \quad$ Cynoglossus bengalensis $8.33 \pm 0.05$. Tetraoclon patoka $8.17 \pm 0.23$ şeklinde belirlemişlerdir. Diler ve ark. (2008) çalışmalarında, taze sudak balığının pH'sını 6.67 \pm 0.14 , tuzlanmış grupta $6.51 \pm 0.15$ olarak tespit etmişlerdir. Doğal kurutmanın 60. günü $6.39 \pm 0.02$, mekanik kurutmada $55^{\circ} \mathrm{C}$ 'de düşük hava akımındaki grupta $6.44 \pm 4.61$, aynı sıcaklık yüksek hava akımındaki grupta $6.47 \pm 0.03$ olarak belirlemişlerdir. Mekanik kurutma grubunun $65^{\circ} \mathrm{C}$ 'de düşük hava akımındaki grubunda $6.55 \pm 0.07$ ve yüksek hava akımındaki grubun pH'sı $0.63 \pm 0.03$ olarak bulunmuştur.

Çalışmada elde edilen değerlerin literatür ile uyumlu olduğu tespit edilmiştir.

Çizelge 3. Kurutulmuş hamsilerin depolama süresi boyunca pH değerlerindeki değişim.

Table 3. Changes in $\mathrm{pH}$ values of dried anchovies during the storage period.

\begin{tabular}{|c|c|c|c|c|}
\hline \multirow{2}{*}{ Günler/Days } & \multicolumn{4}{|c|}{$\mathrm{pH}$} \\
\hline & A grubu/ Group $A$ & B grubu/ Group $B$ & $\mathrm{C}$ grubu/ Group $C$ & D grubu/ Group $D$ \\
\hline Taze balık/ Fresh fish & $6.52 \pm 0.02^{\mathrm{f}}$ & $6.52 \pm 0.002 \mathrm{e}$ & $6.52 \pm 0.02^{\mathrm{d}}$ & $6.52 \pm 0.02 \mathrm{e}$ \\
\hline Tuzlama Sonrası/After dry salting & $6.30 \pm 0.01^{\mathrm{g}}$ & $6.30 \pm 0.01^{\mathrm{f}}$ & $6.30 \pm 0.01^{\mathrm{e}}$ & $6.30 \pm 0.01^{\mathrm{f}}$ \\
\hline $1 . *$ & $6.60 \pm 0.01^{\mathrm{gB}}$ & $6.64 \pm 0.02^{\mathrm{dAB}}$ & $6.68 \pm 0.01^{\mathrm{cA}}$ & $6.67 \pm 0.01 \mathrm{dA}$ \\
\hline 15.* & $6.82 \pm 0.01^{\mathrm{bcdB}}$ & $6.69 \pm 0.01^{\mathrm{cdC}}$ & $6.81 \pm 0.01^{\mathrm{bB}}$ & $6.88 \pm 0.01^{\mathrm{bcA}}$ \\
\hline $30 .^{*}$ & $6.76 \pm 0.02^{\mathrm{dB}}$ & $6.72 \pm 0.02^{\mathrm{cB}}$ & $6.88 \pm 0.01^{\mathrm{aA}}$ & $6.92 \pm 0.02^{\mathrm{bcA}}$ \\
\hline 45.* & $6.81 \pm 0.02^{\mathrm{cdB}}$ & $6.76 \pm 0.03^{\mathrm{bcB}}$ & $6.93 \pm 0.02^{\mathrm{aA}}$ & $6.90 \pm 0.01^{\mathrm{bcA}}$ \\
\hline $60 .^{*}$ & $6.85 \pm 0.01^{\mathrm{abcBC}}$ & $6.81 \pm 0.01^{\mathrm{abC}}$ & $6.89 \pm 0.01^{\mathrm{aAB}}$ & $6.93 \pm 0.02^{\mathrm{bcA}}$ \\
\hline 70.* & $6.90 \pm 0.02^{\mathrm{aBC}}$ & $6.85 \pm 0.02^{\mathrm{aC}}$ & $6.91 \pm 0.01^{\mathrm{aAB}}$ & $6.98 \pm 0.01^{\mathrm{bA}}$ \\
\hline 75.* & $6.88 \pm 0.01^{\mathrm{abB}}$ & $6.87 \pm 0.01^{\mathrm{aB}}$ & $6.92 \pm 0.01^{\mathrm{aB}}$ & $7.08 \pm 0.03^{\mathrm{aA}}$ \\
\hline 80.* & $6.89 \pm 0.01 \mathrm{abBC}$ & $6.86 \pm 0.02^{\mathrm{aC}}$ & $6.95 \pm 0.01^{\mathrm{aB}}$ & $7.10 \pm 0.02^{\mathrm{aA}}$ \\
\hline
\end{tabular}

A. B $\rightarrow$ : Aynı satırda gruplar arasında fark önemli $(\mathrm{P}<0.05)$

a. $b \downarrow$ : Aynı sütunda zamana göre günler arasındaki fark önemli $(\mathrm{P}<0.05)$

*: Kurutma sonrası analizlerin gerçekleştirildiği günler.

Suyun besin maddesindeki durumu; besinin su içeriği ve bulunduğu ortamın bağıl nemliliği arasındaki ilişki yardımıyla tanımlanır ki buna "su aktivitesi $\left(\mathrm{a}_{\mathrm{w}}\right)$ " denir (Pigott ve Tucker. 1990). Su aktivitesi gidalardaki kimyasal, biyokimyasal ve mikrobiyolojik değişimleri sınırlayan kavramların başında gelir (Sikorski. 1990; Caklı. 2007). Gıdadaki su aktivitesi değeri 1'den 0'a doğru düşmeye başladıkça gıdanın dayanıklılığı artmaktadır (Bilişli, 2009).

Çalışmada su aktivitesi değerinin depolama süresince azalma gösterdiği, doğal kurutmada streç ile paket grubunun 70. gün ve 80. günleri arasında, mekanik kurutma streç paket grubunun 45 ve 60 . günleri ile vakum paketleme grubunun 60. gün ve 80 . günleri arasındaki depolama günleri dışındaki depolama günlerinde grup içinde azalmanın istatistiki açıdan anlamlı olduğu belirlenmiştir $(\mathrm{P}<0.05)$. Depolama süresince su aktivitesi değerinin 15. depolama gününden itibaren gruplar arası değer azalışı istatistiki açıdan farklı bulunmuştur $(\mathrm{P}<0.05)$. Bu çalışmada su aktivitesi değeri taze balıkta $0.965 \pm 0.001$ olup tuzlama sonrası $0.847 \pm 0.001$ değerini almıştır. Çalışmanın birinci gününde $\mathrm{A}, \mathrm{B}, \mathrm{C}$ ve $\mathrm{D}$ gruplarında sirasiyla $0.686 \pm 0.002, \quad 0.689 \pm 0.001, \quad 0.712 \pm 0.002$ ve $0.714 \pm 0.001$ değerlerini almıştır. Depolamanın son günü ise bu değerler azalarak $0.495 \pm 0.001$, $0.669 \pm 0.001, \quad 0.680 \pm 0.001$ ve $0.705 \pm 0.001$ değerini almıştır (Çizelge 4). Çalışma sonuna doğru bu değerlerin azalma göstermesinin nedeni ürünün buzdolabının kurutucu etkisi altında olması ve streç film ile paketli ürünlerde hava geçirgenliğinin etkisinden kaynaklandığı düşünülmektedir. 
Diler ve ark. (2008), sudak balığı kurutulması üzerine yaptıkları çalışmada, çiğ balıkta su aktivitesi değerini (aw) 0.970 0.006 , salamura yöntemi ile tuzlanmış balıkta $0.980 \pm 0.006$ olarak tespit edilmiş aralarındaki farkın istatistiksel olarak önemli olmadığ belirtilmiştir. Doğal kurutmaya bırakılan grupta su aktivitesi değeri 1.gün $0.87 \pm 0.03$ olarak bulunmuştur. Mekanik ortamda depolamanın 1. günü su aktivitesi değeri $55^{\circ} \mathrm{C}$ 'de düşük hava akımındaki grupta $0.88 \pm 0.05$, aynı sicaklık yüksek hava akımındaki grupta $0.89 \pm 0.03$ olmuştur. Mekanik kurutma grubunun $65^{\circ} \mathrm{C}$ 'de düşük hava akımındaki grubunda ve yüksek hava akımı grubunda su aktivitesi değerini
$0.88 \pm 0.04$ olarak bildirmişlerdir.

Kung ve ark. (2015), Tayvan'da kurutulmuş uçan balıkları üzerine yaptıkları bir çalışmada kimyasal, mikrobiyolojik ve histamin değerlerini ele almışlardır. Çalışmada farklı 5 bölgeden alınmış örneklerin su aktivitesi değerlerini; Lanyu adası örneklerinde $0.75 \pm 0.02$, Ludau adası örneklerinde $0.80 \pm 0.02$, Liuqiu adasinda $0.74 \pm 0.02$, Kaohsiung adasinda $0.70 \pm 0.01$, Hengchun adasında ise $0.63 \pm 0.01$ olarak bulmuşlardır. Yapılan çalışmadan elde edilen bulgular literatür ile benzerlik göstermektedir.

Çizelge 4. Kurutulmuş hamsilerin depolama süresi boyunca $a_{w}$ değerlerindeki değişim.

Table 4. Changes in $a_{w}$ values of dried anchovies during the storage period.

\begin{tabular}{|c|c|c|c|c|}
\hline \multirow{2}{*}{ Günler/Days } & \multicolumn{4}{|c|}{ Su aktivitesi / Water activity $\left(\mathrm{a}_{\mathrm{w}}\right)$} \\
\hline & A grubu/ Group $A$ & B grubu/ Group B & C grubu/ Group $C$ & D grubu/Group D \\
\hline Taze ballk/ Fresh fish & $0.965 \pm 0.001^{\mathrm{a}}$ & $0.965 \pm 0.001^{\mathrm{a}}$ & $0.965 \pm 0.001^{\mathrm{a}}$ & $0.965 \pm 0.001^{\mathrm{a}}$ \\
\hline Tuzlama Sonrasi/After dry salting & $0.847 \pm 0.001^{\mathrm{b}}$ & $0.847 \pm 0.001^{\mathrm{b}}$ & $0.847 \pm 0.001^{b}$ & $0.847 \pm 0.001^{\mathrm{b}}$ \\
\hline $1 . *$ & $0.686 \pm 0.002^{\mathrm{cB}}$ & $0.689 \pm 0.001^{\mathrm{cB}}$ & $0.712 \pm 0.002^{\mathrm{cA}}$ & $0.714 \pm 0.001^{\mathrm{cA}}$ \\
\hline 15.* & $0.619 \pm 0.001^{\mathrm{dC}}$ & $0.690 \pm 0.001^{\mathrm{cB}}$ & $0.697 \pm 0.001^{\mathrm{dA}}$ & $0.694 \pm 0.001^{\mathrm{fg} A B}$ \\
\hline 30 .* & $0.588 \pm 0.001^{\mathrm{eC}}$ & $0.685 \pm 0.002^{\mathrm{cB}}$ & $0.680 \pm 0.001^{\mathrm{efB}}$ & $0.692 \pm 0.001^{\mathrm{gA}}$ \\
\hline 45.* & $0.550 \pm 0.001^{\mathrm{fD}}$ & $0.661 \pm 0.002^{\mathrm{eC}}$ & $0.685 \pm 0.001^{\mathrm{eB}}$ & $0.695 \pm 0.002^{\mathrm{efgA}}$ \\
\hline $60 . *$ & $0.508 \pm 0.001^{\mathrm{gD}}$ & $0.669 \pm 0.001^{\mathrm{dC}}$ & $0.686 \pm 0.002^{\mathrm{eB}}$ & $0.700 \pm 0.001^{\mathrm{deA}}$ \\
\hline 70.* & $0.493 \pm 0.002^{\mathrm{hD}}$ & $0.665 \pm 0.002^{\mathrm{dcC}}$ & $0.683 \pm 0.002^{\mathrm{eB}}$ & $0.701 \pm 0.002^{\mathrm{deA}}$ \\
\hline 75.* & $0.495 \pm 0.001^{\mathrm{hD}}$ & $0.667 \pm 0.001^{\mathrm{dcC}}$ & $0.675 \pm 0.002^{\mathrm{fB}}$ & $0.699 \pm 0.001^{\text {defA }}$ \\
\hline $80 . *$ & $0.495 \pm 0.001^{\mathrm{hD}}$ & $0.669 \pm 0.001 \mathrm{dC}$ & $0.680 \pm 0.001^{\mathrm{efB}}$ & $0.705 \pm 0.001 \mathrm{dA}$ \\
\hline
\end{tabular}

$\mathrm{A} . \mathrm{B} \rightarrow$ : Aynı satırda gruplar arasında fark önemli $(\mathrm{P}<0.05)$

$a b \downarrow$ : Aynı sütunda zamana göre günler arasındaki fark önemli $(\mathrm{P}<0.05)$

*: Kurutma sonrası analizlerin gerçekleştirildiği günler.

Çalışma boyunca koliform grubu bakteri tespit edilmemiştir. Toplam mezofilik aerobik bakteri analizine bakıldığında ham materyalde $1.97 \pm 0.05 \log _{10}$ kob g olan değer tuzlama sonrası $2.18 \pm 0.05 \log _{10} \mathrm{kob} g$ değerini almış ve depolama süresi boyunca tüm analizlerde toplam aerobik mezofilik bakteri (TMAB), toplam psikrofilik aerobik bakteri (TPAB) ve toplam maya-küf (TMK) değerlerine rastlanmamıştır. İyi kalitedeki balık için toplam bakteri sayısı $5 \log _{10} \mathrm{kob}$ g'ın altında olmalıdır (Varlık ve ark., 1993).

Shiriskar ve ark. (2013), Hint hamsisi Stolephorus indicus (Van Hasselt. 1823) ve Stolephorus commersonii (Lacepède. 1803) üzerinde yapıtıkları çalışmada 5. hafta sonunda yapmış oldukları mikrobiyolojik analiz sonuçlarına göre TMAB değeri başlangiçta $2.0 \times 10^{2} \log$ kob g iken 5 . haftada $6.4 \times 10^{3}$ log kob g olarak arttığını tespit etmişlerdir. Halofilik bakteri türü başlangiçta bulunmazken 4 . haftada $1.05 \times 10^{2} \log$ kob g ve 5 . haftada $4.15 \times 10^{2} \log$ kob g olarak bulmuşlardır.

Kumar ve ark. (2013) doğal ve mekanik yöntem ile kurutulmuş Labeo gonius balık filetolarına uygulanan mikrobiyoloji analizi sonucunda depolamanın 6 . ayındaki polietilen ambalajla depolanan balıkların doğal kurutulmaya tabii tutulan grupta $1.50 \times 10^{3} \mathrm{log}$ kob g iken mekanik kurutulan grupta $1.32 \times 10^{3} \log \mathrm{kob}$ g olarak bulunmuştur. Mikrobiyoloji analizleri sonucu mikrobiyal yük bulunmamasını nedeni üründe bulunan nem içeriğinin kurutma sonrasında çok düşük seviyelerde olmasıdır.

Balıklarin duyusal analizine ait bulgular incelendiğinde; gruplarda ve gruplar arasinda depolamanın ilk gününden itibaren depolama süresine bağlı olarak renk, koku, tat, tekstür ve genel beğeni duyusal değerlendirme puanlarında azalmanın istatistiki açıdan anlamlı olduğu bulunmuştur $(\mathrm{P}<0.05)$. Doğal yöntemle kurutularak streç film ile paketlenmiş balıklar duyusal yönden en beğenilen ve uzun depolama süresine sahip olan grup olarak belirlenmiştir. Duyusal analiz sonuçlarma göre değerlendirmede kullanılan puan kriterleri bakımından 3 puanın altında puanlanan ürünler "Tüketilemez" olarak değerlendirilmiş olup 80. günde doğal kurutulan streç paketlenen A grubu. 70. günde doğal kurutulan vakum paketlenen $B$ grubu. 60. günde mekanik kurutulan streç paketlenen $\mathrm{C}$ grubu. 45. günde mekanik kurutulan vakum paketlenen $\mathrm{D}$ grubu tespit edilen günlerde duyusal yönden bozulmuştur (Çizelge 5).

Chavan ve ark. (2008), çalışmalarında mekanik kurutmanın tekstür, koku ve genel beğeni üzerinde yapılan puanlamalarda yüksek puanlara sahip 
olduğunu bildirmişlerdir. Ojutiku ve ark. (2009), Hyperopisus bebe occidentalis balık türünü güneş çadır kurutucusu ve geleneksel doğal kurutma yöntemleri arasında duyusal açıdan yapılan değerlendirmelerde balıkların tekstür ve renk değişimleri her iki grupta da benzer olduğu tespit etmişlerdir.

Çizelge 5. Tüm kurutulmuş ürün gruplarına ait duyusal analiz bulguları.

Table 5. Sensory analysis result of all dried product groups.

\begin{tabular}{|c|c|c|c|c|c|c|c|c|c|}
\hline \multirow{2}{*}{\multicolumn{2}{|c|}{ Grup/Group }} & \multicolumn{8}{|c|}{ Günler / Days } \\
\hline & & 1. & 15. & 30. & 45. & 60. & 70. & 75. & 80. \\
\hline \multirow{5}{*}{ A } & $*$ & $7.50 \pm 0.32^{\mathrm{Aa}}$ & $7.60 \pm 0.24^{\mathrm{Aab}}$ & $6.60 \pm 0.10^{\mathrm{Ba}}$ & $5.80 \pm 0.12^{\mathrm{Ba}}$ & $5.80 \pm 0.12^{\mathrm{Ba}}$ & $3.60 \pm 0.19^{\mathrm{Cb}}$ & $3.50 \pm 0.12^{\mathrm{C}}$ & $3.50 \pm 0.12^{\mathrm{C}}$ \\
\hline & $* *$ & $7.60 \pm 0.19^{\mathrm{Aab}}$ & $7.10 \pm 0.10^{\mathrm{ABab}}$ & $7.1 \pm 0.10^{\mathrm{ABa}}$ & $6.40 \pm 0.19^{\mathrm{BCa}}$ & $5.90 \pm 0.10^{\mathrm{Ca}}$ & $4.30 \pm 0.12^{\mathrm{Da}}$ & $3.00 \pm 0.32^{\mathrm{E}}$ & $1.20 \pm 0.12^{\mathrm{F}}$ \\
\hline & $* * *$ & $8.10 \pm 0.10^{\mathrm{Aa}}$ & $8.00 \pm 0.16^{\mathrm{Aa}}$ & $7.5 \pm 0.16^{\mathrm{ABa}}$ & $6.80 \pm 0.12^{\mathrm{BCa}}$ & $6.10 \pm 0.19 \mathrm{Ca}$ & $4.80 \pm 0.12^{\mathrm{Da}}$ & $3.00 \pm 0.16^{\mathrm{E}}$ & $1.60 \pm 0.29^{\mathrm{F}}$ \\
\hline & $* * * *$ & $7.40 \pm 0.24^{\mathrm{ABa}}$ & $7.70 \pm 0.20^{\mathrm{Aa}}$ & $7.60 \pm 0.19^{\mathrm{Aa}}$ & $6.70 \pm 0.12^{\mathrm{BCa}}$ & $6.20 \pm 0.12^{\mathrm{Ca}}$ & $5.10 \pm 0.19^{\mathrm{Da}}$ & $3.10 \pm 0.10^{\mathrm{E}}$ & $3.00 \pm 0.16^{\mathrm{E}}$ \\
\hline & $* * * * *$ & $8.20 \pm 0.20^{\mathrm{Aa}}$ & $7.90 \pm 0.10^{\mathrm{ABa}}$ & $7.20 \pm 0.12^{\mathrm{BCa}}$ & $6.80 \pm 0.12^{\mathrm{Ca}}$ & $6.30 \pm 0.12^{\mathrm{Ca}}$ & $4.90 \pm 0.19^{\mathrm{Da}}$ & $3.50 \pm 0.32^{\mathrm{E}}$ & $2.10 \pm 0.37^{\mathrm{F}}$ \\
\hline \multirow{5}{*}{ B } & $*$ & $7.40 \pm 0.24^{\mathrm{ABa}}$ & $7.90 \pm 0.10^{\mathrm{Aa}}$ & $6.80 \pm 0.25^{\mathrm{BCa}}$ & $6.20 \pm 0.12^{\mathrm{Ca}}$ & $6.20 \pm 0.12^{\mathrm{Ca}}$ & $4.30 \pm 0.20^{\mathrm{Da}}$ & - & - \\
\hline & $* *$ & $7.20 \pm 0.20^{\mathrm{Ab}}$ & $7.40 \pm 0.19^{\mathrm{Aa}}$ & $6.90 \pm 0.10^{\mathrm{ABa}}$ & $6.20 \pm 0.12^{\mathrm{BCab}}$ & $5.50 \pm 0.16^{\mathrm{Ca}}$ & $2.40 \pm 0.37 \mathrm{Db}$ & - & - \\
\hline & $* * *$ & $7.70 \pm 0.20^{\mathrm{Aa}}$ & $7.70 \pm 0.12^{\mathrm{Aa}}$ & $6.80 \pm 0.12^{\mathrm{Bb}}$ & $6.10 \pm 0.10^{\mathrm{Cb}}$ & $5.30 \pm 0.20^{\mathrm{Da}}$ & $2.50 \pm 0.16^{\mathrm{Eb}}$ & - & - \\
\hline & $* * * *$ & $7.30 \pm 0.20^{\mathrm{Aa}}$ & $7.10 \pm 0.10^{\text {Aab }}$ & $6.90 \pm 0.24^{\mathrm{Aab}}$ & $5.90 \pm 0.10^{\mathrm{Bb}}$ & $6.00 \pm 0.16^{\mathrm{Ba}}$ & $4.30 \pm 0.12^{\mathrm{Cb}}$ & - & - \\
\hline & $* * * * *$ & $8.40 \pm 0.24 \mathrm{Aa}$ & $7.20 \pm 0.12^{\mathrm{Bb}}$ & $6.50 \pm 0.16^{\mathrm{BCa}}$ & $6.10 \pm 0.10^{\mathrm{CDb}}$ & $5.40 \pm 0.19 \mathrm{Da}$ & $2.30 \pm 0.12^{\mathrm{Eb}}$ & - & - \\
\hline \multirow{5}{*}{ C } & * & $7.80 \pm 0.20^{\mathrm{Aa}}$ & $6.20 \pm 0.12^{\mathrm{BCc}}$ & $6.50 \pm 0.22^{\mathrm{Ba}}$ & $5.50 \pm 0.22^{\mathrm{Ca}}$ & $3.80 \pm 0.12^{\mathrm{Db}}$ & - & - & - \\
\hline & $* *$ & $7.40 \pm 0.24^{\mathrm{Ab}}$ & $6.70 \pm 0.12^{\mathrm{ABb}}$ & $6.10 \pm 0.10^{\mathrm{BCb}}$ & $5.40 \pm 0.24^{\mathrm{Cb}}$ & $4.10 \pm 0.10^{\mathrm{Db}}$ & - & - & - \\
\hline & $* * *$ & $7.50 \pm 0.16^{\mathrm{Aa}}$ & $7.00 \pm 0.16^{\mathrm{Ab}}$ & $6.80 \pm 0.12^{\mathrm{Ab}}$ & $5.20 \pm 0.12^{\mathrm{Bc}}$ & $2.30 \pm 0.34^{\mathrm{Cb}}$ & - & - & - \\
\hline & $* * * *$ & $7.40 \pm 0.24^{\mathrm{Aa}}$ & $6.60 \pm 0.19 \mathrm{ABb}$ & $6.5 \pm 0.22^{\mathrm{Bb}}$ & $5.60 \pm 0.24^{\mathrm{Cb}}$ & $5.10 \pm 0.10^{\mathrm{Cb}}$ & - & - & - \\
\hline & $* * * * *$ & $8.30 \pm 0.20^{\mathrm{Aa}}$ & $7.10 \pm 0.10^{\mathrm{Bb}}$ & $6.40 \pm 0.24^{\mathrm{Ba}}$ & $5.20 \pm 0.12^{\mathrm{Cc}}$ & $2.00 \pm 0.35^{\mathrm{Db}}$ & - & - & - \\
\hline \multirow{5}{*}{ D } & $*$ & $7.60 \pm 0.24^{\mathrm{Aa}}$ & $7.10 \pm 0.10^{\mathrm{ABb}}$ & $6.40 \pm 0.10^{\mathrm{Ba}}$ & $4.50 \pm 0.22^{\mathrm{Cb}}$ & - & - & - & - \\
\hline & $* *$ & $8.40 \pm 0.24^{\mathrm{Aa}}$ & $6.70 \pm 0.12^{\mathrm{Bb}}$ & $5.90 \pm 0.10^{\mathrm{Cb}}$ & $3.50 \pm 0.22^{\mathrm{Dc}}$ & - & - & - & - \\
\hline & $* * *$ & $8.00 \pm 0.27 \mathrm{Aa}$ & $6.70 \pm 0.12^{\mathrm{Bb}}$ & $5.60 \pm 0.24^{\mathrm{Cc}}$ & $2.40 \pm 0.24^{\mathrm{Dd}}$ & - & - & - & - \\
\hline & $* * * *$ & $7.50 \pm 0.22^{\mathrm{Aa}}$ & $7.10 \pm 0.10^{\mathrm{ABab}}$ & $6.5 \pm 0.22^{\mathrm{Bb}}$ & $4.40 \pm 0.19^{\mathrm{Cc}}$ & - & - & - & - \\
\hline & $* * * * *$ & $7.80 \pm 0.25^{\mathrm{Aa}}$ & $6.80 \pm 0.12^{\mathrm{Bb}}$ & $5.20 \pm 0.25^{\mathrm{Cb}}$ & $2.20 \pm 0.25^{\mathrm{Dd}}$ & - & - & - & - \\
\hline
\end{tabular}

$\mathrm{A}, \mathrm{B} \rightarrow$ : Aynı satırda gruplar arasında fark önemli $(\mathrm{P}<0.05)$

$\mathrm{a}, \mathrm{b} \downarrow$ : Aynı sütunda zamana göre günler arasındaki fark önemli $(\mathrm{P}<0.05)$

$*$ : Renk. ${ }^{* *}$ : Koku. $* * *$ : Tat. $* * * *$ : Tekstür. $* * * * *$ : Genel Beğeni.

\section{SONUÇ}

Duyusal değerlendirme, bir gidanın değerlendirilmesinde ilk ve en önemli göstergeyi ortaya koymaktadır. Ürün kalitesi değerlendirilirken kimyasal ve mikrobiyolojik açıdan kalite sınırları içinde kalsa dahi duyusal açıdan kabul edilemez olduğunda bozulmuş olarak değerlendirilir ve bu ürünün raf ömrü duyusal değerlendirmeye göre belirlenir.

Kurutulmuş hamsi balığının buzdolabı koşullarındaki raf ömrü, mikrobiyoloji analizleri sonucu ürün gruplarında bir bozulma gözlenmediğinden kimyasal değerlendirmelerde TVB-N ve TBA değerleri raf ömrü açısından dikkate alınmamıştır. Bu sebeple raf ömrü duyusal analiz sonucuna göre belirlenmiştir. Elde edilen sonuçlara göre doğal kurutmanın mekanik kurutmaya göre daha fazla raf ömrüne sahip olduğu belirlenmiştir. Her ne kadar vakum paketleme işlemi ürünleri kimyasal açıdan korusa da duyusal açıdan vakumlanmamış ürünler daha çok ilgi görmüştür. Panelistler tarafinda düşük puan alarak kalitesini kaybeden ve tüketilemez olarak değerlendirilen ilk grup 45. günde $2,20 \pm 0,25$ puan ile $\mathrm{D}$ grubu olmuştur. Diğer gruplar sirasiyla C (60. gün), B (70. gün), A (80. gün) grubu olmuştur

Kurutulmuş ürünlerin sade tüketiminin yanı sıra soslanarak ya da salata gibi ürünlerin içerisine konularak tüketilmesi su ürünleri tüketim şekillerine alternatif oluşturabilecektir. Literatürde balıkların farklı şekillerde kurutulması ile ilgili az çalışma mevcuttur. Farklı türdeki balıklar, farklı kurutma sıcaklıkları, farklı hava akım değerleri veya farklı paketleme yöntemleri geliştirilerek işlenip literatüre güncel bilgiler kazandırılabilir. Tüketicinin beğenisine göre alternatif kurutma yöntemleri de denenip piyasaya sunulabilir ve bu şekilde ekonomiye katkı sağlanabilir.

\section{TEŞEKKÜR}

Bu çalışma, Fatih YAVUZ' un yüksek lisans tezinin bir parçasıdır ve Sinop Üniversitesi Rektörlüğü Bilimsel Araştırma Projeleri (BAP) birimi tarafından SÜF1901-15-03 nolu proje numarası ile desteklenmiştir.

\section{Çıkar Çatışması Beyanı}

Tüm yazarlar makalelerinde, sonuçları veya yorumları etkileyebilecek herhangi bir maddi veya diğer asli çıkar çatışması olmadığını beyan ederler.

\section{Araştırmacıların Katkı Oranı Beyanı}

Yazarlar makaleye eşit oranda katkı sağlamış oldukların beyan ederler. 


\section{KAYNAKLAR}

Altuğ T. 1993. Duyusal Test Teknikleri. E.Ü. Müh.

Fak. Ders Kitapları, Yayın No: 28, İzmir.

Anonim 2020. https://hsgm.saglik.gov.tr/tr/ beslenme /temel-besin-gruplari.html (Alınma tarihi: 25.05.2020).

Azam K, Basher MZ. Asaduzzaman MH, Hossain MM, Ali MY 2003. Biochemical Quality Assessment of Fourteen Selected Dried Fish. Univ. J. Zool. Rajshahi Univ. 22: 23-26.

Baysal T, Rayman A, Bozkır H 2013. Kurutulmuş ürünlerin ambalajlanması ve saklanması. 11. Ulusal Tesisat Mühendisliği Kongresi, 17-20 Nisan 2013, 37-41 sy. İzmir

Bilişli A 2009. Gıda Kimyası. Sidas Medya Ltd. Şti., Seher Matbaacılık, İzmir, 237 sy.

Bingöl G 2010. Gıda İşlemede Kurutma Teknolojilerinin Temel ilkeleri. İstanbul Sanayi Odası, No: 2010/4, İstanbul, 114 sy.

Chavan BR, Yakupitiyage A, Kumar S, Rakshit SK 2008. Experimental Investigation on Biochemical. Microbial and Sensory Properties of Mackerel (Rastrilliger kangurta) Dried by Solar-Biomass Hybrid Cabinet Dryer. Journal of Food. Agriculture and Environment 6(3-4): 167-171.

Cohen JS, Yang TCS 1995. Progress in food dehydration. Trends in Food Science and Technology 6: 20-25.

Curran CA, Nicoladies L, Poulter RG, Pors J 1980. Spoilage of Fish from Hong Kong at Different Storage Temperatures. Trop Sci. 22: 367-382.

Çaklı Ş 2007. Su Ürünleri İşleme Teknolojisi-1. Ege Üniversitesi $\mathrm{Su}$ ürünleri Fakültesi Yayınları, No:76, İzmir, 696 sy.

Diler A, Güner A, Altun S, Ekici S 2008. Farklı Sicaklık ve Hava Akım Hızında Kurutmanın Sudak Balığ 1 (Stizostedion lucioperca) Filetolarının Kalite Niteliklerine Etkisi. Vet. Bil. Dergisi 24(1): 77-86.

Düzgüneş O, Kesici T, Gürbüz F 1993. İstatistik Metotları. II. Baskı, A.Ü. Ziraat Fak. Yayınları, No:1291, Ankara, 861 sy.

Erdem M, Varol Y, Öztop HF, Türkbay İ 2016. Balığın Kuruma Davranışı Üzerinde Parça Etkisi ve Sistemin Enerji Gereksiniminin İncelenmesi. Frrat Üniv. Müh. Bil. Dergisi 28(2): 89-98.

Geankoplis CJ 1993. Transport Processes and Unit Operations. 3rd Ed., Prentice Hall.Englewood Cliffs, New Jersey, 1009 pp.

Göktan D 1990. Gıdaların Mikrobiyal Ekolojisi. Ege Üniversitesi, Mühendislik Fak. Yayın No:21, Ege Üniversitesi Basımevi, İzmir, 292 sy.

Gürgün V, Halkman KA 1990. Mikrobiyolojide Sayım Yöntemleri. Gıda Teknolojisi Dergisi, No:7, Ankara, $146 \mathrm{sy}$.

İnal T 1992. Besin Hijyeni Hayvansal Gıdaların Sağlık Kontrolü. 2. Baskı. Final Ofset A.Ş., İstanbul, 783 sy.

Kaba N, Yücel Y, Çorapcı B, Özer Ö, Eryaşar K 2012.
Shelf Life of Anchovy (Engraulis engrasicolus. L.1758) Patties Stored at $4^{\circ} \mathrm{C}$. Akademik Gida 10(4): 19-23.

Keleş F. 1998. 'Gıda ambalajlama ilkeleri'. Atatürk Üniversitesi Ziraat Fakültesi Gıda Mühendisliği Bölümü, Erzurum 2002.

Köstekli B, Keskin İ, Erdem ME 2019. Determination of Quality Changes of Hot Smoked Rainbow Trout (Oncorhynchus mykiss, Walbaum 1792) Fillets Kept in The Deep Freeze For Different Storage Time Periods. Fresenius Environmental Bulletin, 28(8): 5962-5972.

Kumar A, Singh P, Danish M 2013. Changes in Proximate. Biochemical and Microbiological Characteristics of Dried Labeo Gonius Fillets During Storage at Room Temperature. African Journal of Biotechnology 12(20): 2997-3005.

Kung HF, Huang CY, Lin CM, Liaw LH, Lee YC, Tsai YH 2015. The Histamine Content of Dried Flying Fish Products in Taiwan and The İsolation of Halotolerant Histamineforming Bacteria. Journal of Food and Drug Analysis 23: 335-342.

MEGEP 2008. Su Ürünleri İşleme Teknikleri. MEB. Ankara. 60 sy.

Ojutiku RO, Kolo RJ, Mohammed ML 2009. Comparative Study of Sun Drying and Solar Tent Drying of Hyperopisus Bebe Occidentalis. Pakistan Journal of Nutrition 8(7): 955-957.

Özdamar K 1999. Paket Programlar ile İstatistiksel Veri Analizi. (10. baskı). Nisan Kitapevi. Eskişehir. 474 sy.

Pigott GM, Tucker BW 1990. Seafood Effects of Technology on Nutrition. Marcel Dekker. Inc. New York, 384 pp.

Roger S, John I, Mark W, Page P 1987. General microbiology. Fifth edition. published by Macmillan Education Ltd. Houndmills. Basingstoke. Hampshire. RG21 2xs and London, 689 pp.

Shiriskar DA, Khedkar GD, Lior D 2013. Production Of Salted And Pressed Anchovies (Stolephorus sp.) and I't's Quality Evaluation During Storage. Journal of Food Science and Technology 50(6): $1172-1178$.

Sikorski ZE 1990. Seafood: Resources. Nutritional Composition and Preservation. CRC Press. Inc., ISBN: 0-8493-5985-6. Florida, 248 pp.

Smith G, Hole M, Hanson SW 1992. Assessment of Lipid Oxidation in Indonesian Salted-Dried Marine Catfish (Arius thalassinus). Journal of the Science of Food and Agriculture 51: 193-205.

Srinivasa TK, Viswanathan Nair PG, Kanderan MK, Prabhu PW, Gopakumar K 1998. Shelf Life of Dried Anchoviella in Flexible Packaging Materials. Food Control 9(4): 205-209.

Turan H 1996. Farklı tuzlama yöntemlerinin değişik balıklarda kalite ve saklama süresine etkileri. Ondokuz Mayıs Üniversitesi Fen Bilimleri Enstitüsü. Yüksek Lisans Tezi, 74 sy. 
Varlık C, Uğur M, Gökoğlu N, Gün H 1993. Su Ürünlerinde Kalite Kontrol İlke ve Yöntemleri. Gıda Teknolojisi Derneği Yayın No: 17. Ankara, 174 sy.

Yakupitiyage A 1994. Analytical Techniques in Fish Nutrition. Laboratory Manual for AE 52; Fish
Nutrition and Feed Technology. Asian Institute of Technology. Bangkok.

Yapar A 1999. Ǘç Farklı Tuz Konsantrasyonu Kullanılarak Hazırlanan Tuzlanmış Hamsi (Engraulis encrasicolus)'lerde Kalite Değişimi. Tr. J. Veterinary and Anim. Sci. 23(3): 441-445. 